\title{
Design Science Research and Activity Theory in ICT4D: Developing a socially relevant ICT platform for elderly women in remote rural South Africa
}

\author{
Ronel Smith ${ }^{1,2}$, Marita Turpin ${ }^{2 *}$ \\ ${ }^{1}$ CSIR Meraka Institute, Pretoria, South Africa \\ rsmith2@csir.co.za \\ ${ }^{2}$ Department of Informatics, University of Pretoria, Pretoria, South Africa \\ marita.turpin@up.ac.za
}

\begin{abstract}
ICT4D projects in rural communities face many challenges to successful execution. These include the development of an ICT artifact which is suited to the needs of a specific community, as well as a complex socio-cultural context which can have unexpected impacts on an ICT4D project. In Mafarafara, a remote rural community in South Africa's Limpopo province, researchers who were using a Design Science Research framework to guide the development of an ICT platform recognized the importance and potential impact of unvoiced social and political issues. Managing these dynamics are important for not only a better understanding of the community, but also for the success and sustainability of the project. Activity theory is used to complement the DSRM to make these social aspects visible, thus contributing to the success of the project. Two examples of the socio-political dynamics are described using the activity theory concepts of tension and hierarchical activity.
\end{abstract}

Keywords. Design Science Research, Activity Theory, ICT4D, South Africa, rural women, empowerment

\section{Introduction}

Despite wide-spread acceptance that ICT4D is a socio-technical discipline, theories focusing on the acceptance and resistance of technology, and understanding technology adoption, still predominate ICT4D research [1, 2]. In a comprehensive classification of the theories used in ICT4D, Andersson and Hatakka [2] highlight that very few ICT4D researchers apply theories from outside the domain. In response, Andersson and Hatakka [2], and Karanasios [3] argue that ICT4D researchers should use theories which allow the focus to be placed on the social context, poverty reduction, and development. More use should be made of theories from other domains such as gender studies and education [2]. This would allow for an investigation of the relationship between technology, human activity, and development, aspects that are particularly relevant for this research project, which is aimed at providing elderly women in a 
remote rural community in South Africa's Limpopo province with access to an ICT platform designed to meet their stated needs.

Within a case study context, this paper presents the theoretical framework which underpins a research project. It discusses how, the social and political dynamics of a remote rural community can be made visible and taken into account by applying activity theory within a design science research framework.

The Design Science Research Methodology (DSRM) formulated by Peffers, Tuunanen, Rothenberger \& Chatterjee [4] provides the overall framework for the research project. Activity theory is simultaneously applied during each phase of the DSRM. Activity theory is used to make visible the relationships between the women, the ICT platform and the researchers, and to describe the social and political dynamics in the community. Activity theory is hence used to complement the DSRM by surfacing and emphasizing social aspects that are important, not only for better understanding of the community but also for the success and sustainability of the project. This study contributes to the theoretical body of knowledge in ICT4D by demonstrating how the combination of Design Science Research (DSR) and activity theory can lead to a more appropriate practice theory for ICT4D.

The theoretical framework of the study is the main focus of the paper. It proceeds with a discussion of DSR in the ICT4D domain, followed by a presentation of the case study. The role of activity theory in this research project and ICT4D is then explored. Finally, the paper discusses the theoretical framework that incorporates activity theory in the Design Science Research Methodology.

\section{Design science research in ICT4D}

\subsection{Overview of design science research}

DSR is a creative problem solving methodology that focuses on creation and innovation with the purpose of changing "existing situations into preferred ones" [5, 6, 7]. DSR therefore creates a new reality, rather than attempting an explanation of the existing reality [5] [7]. Through its focus on problem solving, DSR aims to "produce and apply knowledge of tasks or situations in order to create" new, innovative and effective artifacts, rather than the creation of general theoretical knowledge [8]. The production of innovative new knowledge to solve a specific problem differentiates DSR from routine design [9]. DSR researchers value relevance, making a visible impact, creative problem solving, and efficient ways to accomplish the desired end result. Key criteria for the assessment of a DSR project pertains to questions of pragmatic validity (does the artifact produce the intended result and is it effective: does it work as it is supposed to) and practical relevance (does the artifact make a valuable contribution to solving a significant real-life problem) [10].

Various DSR frameworks have been developed since Simon published The Sciences of the Artificial in 1996. Concepts central to these frameworks focus on problem identification, the design and build of a prototype solution, evaluation and testing of the solution, and analysis and reflection. 
DSR produces both tangible and intangible artifacts which includes constructs, models, methods, instantiations, and better theories [4] [8, 9].

Changes in the Information Systems (IS) domain over the past two decades have led to DSR becoming an established research methodology in IS. Various authors including Drechsler and Hevner [11], Goldkuhl and Lind [12], and Iivari [13] argue that DSR is appropriate for the IS domain because it addresses the centrality of the IT artefact in IS, lends increased legitimacy to the discipline's creative aspects, and increases the relevance of IS research.

\subsection{Design science research in ICT4D}

The application of DSR in ICT4D is a more recent, but evolving phenomenon. The synergies between ICT4D and DSR are discussed below.

ICT4D has been described as a "complex socio-technical activity in which the social and the technical negotiate and evolve together", to address "ill-structured and wicked problems” [14]. Wicked problems result from, amongst others, ill-defined environmental contexts, complex relationships, and a reliance on teamwork to deliver relevant and effective solutions [15]. As argued by Rittel and Webber [16], DSR is particularly suited to managing wicked problems.

Although firmly rooted in engineering, DSR is applicable in the ICT4D domain because it focuses on phenomena which result from the interaction of a social system (the elderly women) and a technical system (the ICT platform) [11] [17]. Drechsler and Hevner [11] recently proposed the addition of the fourth "change and impact" cycle to Hevner's Three-cycle view of DSR to allow the latter to better deal with the dynamic contexts in which DSR projects are conducted, as well as the impact of the introduction of an artifact within a context.

Pragmatic validity and utility is key in DSR [10]. Towards achieving these aims, DSR allows for the identification of a specific problem that is important to the community in which a development project is being executed; and for the development of a relevant, innovative solution. Validity and utility of the ICT4D intervention can address failure as a result of irrelevant solutions which are enforced from outside. Dearden, Light, Kanagwa \& Rai [18] define the term “Technical ICTD”, and call for innovation and adaptation of technologies to ensure that technical ICT research makes a positive contribution to development. In this context, and with ICT4D being a practical discipline, DSR is a suitable research methodology in the ICT4D domain [17].

\section{Case study}

The aim of the research project was threefold: (1) with the women as co-creators, design an ICT platform adapted to suit the specific requirements of elderly rural women with respect to physical design, content and applications; (2) develop a framework aimed at improving the adoption of an ICT platform which can empower elderly women in a rural community in South Africa; and (3) gain an improved understanding of the role that ICTs can play in rural development. 
The research project was operationalized through a DSR process consisting of three phases. The various aspects of the project were investigated through the use of case study research. As depicted in Fig. 2, the study followed an iterative process of designing, developing, testing and evaluating an ICT platform in a rural community with the active participation of the elderly women. To date, the three phases of the DSR process indicated in Fig. 2 have been completed while the analysis of data that were collected as part of the case study is ongoing.

\subsection{The situation of elderly rural women in South Africa}

Elderly rural women form the most deprived population group in South Africa [19, 20]. Apartheid, enduring patriarchal prejudice, discriminatory customary laws, and a dearth of initiatives aimed at their empowerment have conspired to leave these women in a dire situation [19] [21]. They are marginalized, mostly illiterate, isolated in their communities, and have extremely limited access to resources [20] [22]. Despite the mentioned disadvantages that elderly rural women face, and as a result of men working away from their communities, the women frequently care for a multigenerational household, with their R1,520 (just over \$100) monthly old age grant as the only household income [20].

Empowering and improving the economic condition of rural women has been shown to have a positive multiplier effect which results in improved nutrition and health, as well as access to education for their family members [21] [23]. The prevailing majority opinion is that Information and Communication Technologies (ICTs) have an important role to play as vehicle through which rural women in particular can empower themselves economically and socially [24].

\subsection{Mafarafara}

The research project was conducted in Mafarafara, a small very remote rural community in the Greater Tubatse local municipality in South Africa's Limpopo province. The community is surrounded by mountains, and can only be reached by a $4 \times 4$ vehicle due to the poor condition of the access road that passes through the Tubatse river. The community is completely isolated when the river is in flood. There is limited and unreliable cell phone coverage. According to Mma C (Mma is a respectful form of address for elderly women), the project champion, there are 280 households with a population ranging between 1700 and 2000 people in Mafarafara [25]. The majority of families in Mafarafara survive on government grants and subsistence agriculture. The lack of infrastructure development has a severely negative impact on the community's quality of life in general, and on the elderly women in particular. Although there are connections for running water, water is not available because the main water pump was stolen. Pre-paid electricity was installed in a section of the community in October 2013. However, many houses have electricity sockets installed without access to electricity, and many inhabitants cannot afford to pay for electricity. Mafarafara still resides under the tribal chieftaincy tradition. 


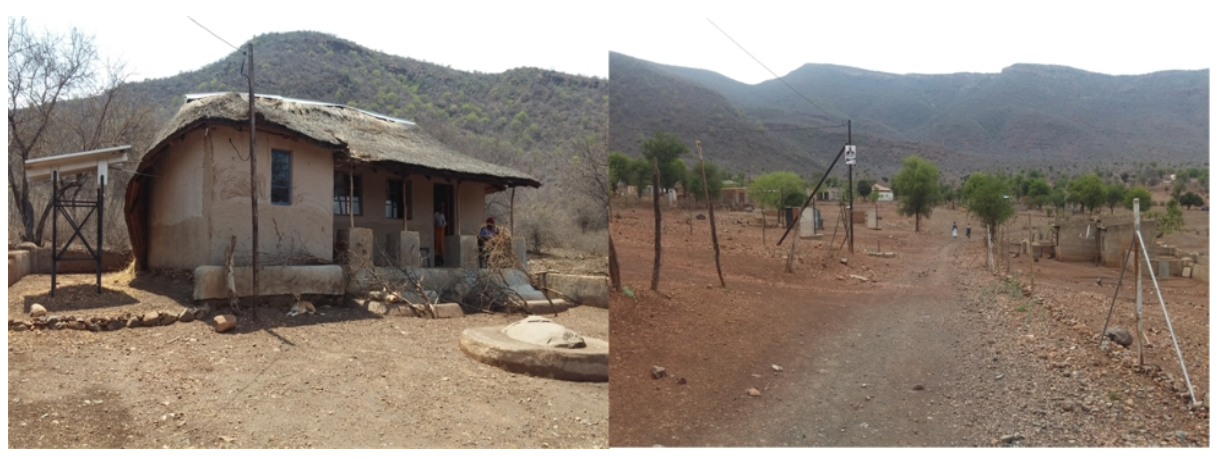

Fig. 1. Community centre where ICT platform is installed, and Mafarafara village

\section{$4 \quad$ Activity theory in ICT4D}

\subsection{Social and political dynamics}

The project has been executed by the Council for Scientific and Industrial Research (CSIR) in South Africa. Their research team all have significant experience in various aspects of ICT4D, ranging from designing ICTs for remote rural areas, deploying technology projects in rural areas, and conducting various types of research in these communities. Particular attention was therefore paid to honoring local customs and acting accordingly.

To this end, the site visits were conducted by Sepedi (local language) speaking researchers. All focus group sessions and one-on-one interviews were conducted in Sepedi. The project lead (one of the authors) is English speaking, necessitating the transcription and translation of the Sepedi audio and video recordings to English before the data could be processed. Although debriefs were conducted after each site visit, an in-depth analysis of the transcriptions revealed complex social and political dynamics in the community-between the elderly women themselves, and between the women and the research team-the extent of which was not evident during the debriefing sessions. These dynamics, as well as the agency of the women, directly impact on the success of this project, and must be made visible and taken into account to ensure that the final artifact meets the DSR criteria for a successful project, namely validity and relevance. However, given its roots in engineering, DSR neglects the social aspects of the complex environments in which ICT4D initiatives are executed.

The need to make sense of these human dynamics in an ICT4D project leads Karanasios [3] and Hashim and Jones [26], amongst others, to argue for the suitability of activity theory in ICT4D because it provides the researcher with "a well-developed model of the dynamics of human activity” in developmental contexts [3]. 


\subsection{Activity theory}

Activity theory, which is defined by Kaptelinin and Nardi [27] as a "general theoretical framework for the analysis of human and communal action in the world", can provide the structure for articulating and studying the social aspects highlighted above. Using Gregor [28], activity theory can be described as a theory for analysis, and for describing and studying design rather than as a theory for prediction.

In this research study, Engeström's [29] third generation activity theory is applied in the Design \& Development and Demonstration activities of the DSRM. The belief that the "human mind emerges, exists, and can only be understood within the context of meaningful, goal-oriented, and socially determined interaction between human beings and their material environment" is foundational in activity theory. This interaction (activity) is socially and culturally determined. By emphasizing socio-cultural factors, the interaction between human actors and their environments, and the concept of tool mediation, activity theory can provide a suitable foundation for the Design \& Development and Demonstration activities of this research project [27] [30].

The concept of tool mediation allows for a specific focus on people's interaction with each other and with artifacts [27]. In the context of Mafarafara, activity theory therefore allows the researchers to explore the relationships between the women themselves, the women and the ICT platform, as well as the relationship between the women and the researchers.

Activity theory is well established in the ICT4D domain, where it serves to highlight and frame the importance of the social and development aspects of ICT implementation and use [3] [27]. Activity theory provides researchers with a tool to describe and gain an understanding of the cultural, inter-personal, and ethnographic dimensions involved with the introduction of an ICT artifact to a community [3].

Karanasios [3], highlighting that activity theory is not excessively prescriptive, states that it can easily draw on or be used with or within other theories to produce deeper knowledge than would otherwise be the case. Accordingly, in this study, activity theory is used to complement the DSRM by providing a means to describe and understand the social and political dimensions of the social context that became evident during the study.

Due to space limitations, which preclude an in-depth discussion of the project as a whole, two examples are given where the application of activity theory makes visible the social and political dynamics. The first example illustrates the activity theory notion of tensions between components and the second illustrates the structure of human activity.

\section{$5 \quad$ Theoretical framework in this project}

This section discusses the theoretical framework underpinning the research study, and provides a short overview of how it should be applied. The third iteration of phase 2 of the DSRM is then used to illustrate the application of the framework in the Mafarafara case study by means of example stories. 
Fig. 2 describes the three phases of the DSRM, positions activity theory in the design \& development, demonstrates activities of the three phases, and shows how the outputs of each phase are integrated towards the final artifacts.

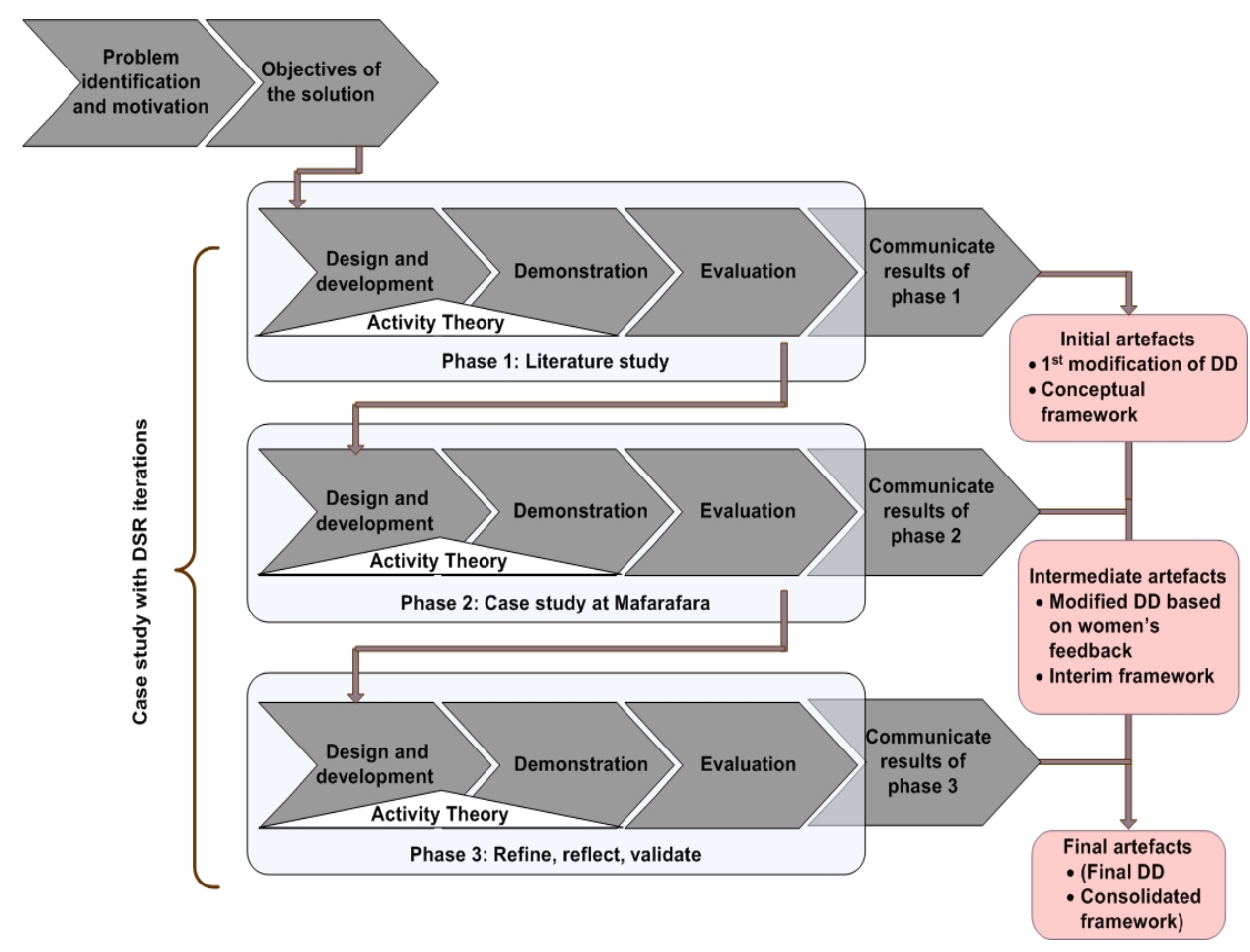

Fig. 2. DSRM phases with activity theory applied in the design \& development and demonstration activities (adapted from Peffers, et al. [4] and Herselman and Botha [7])

\subsection{Design Science Research Methodology}

The six activities of the DSRM [4] in this project can be described as follows:

1. Identify the problem and motivate why it should be addressed: The problems that this research project seeks to address are the plight of elderly rural women and the low success rate of ICT4D initiatives.

2. Define objectives of the solution: The objective of the created artifacts are an improved success rate of ICT4D initiatives in rural areas; the design, development, testing and improvement of an ICT artifact for use by elderly rural women; and influencing government decision-making.

3. Design and develop: Design and develop various artifacts over three project phases, with three iterations in phase two. The learning from each iteration informs the following iteration towards finalization of the framework and ICT artifact. 
4. Demonstrate: The created artifacts are demonstrated in the context of a case study. An iterative process is followed in Mafarafara.

5. Evaluate: Each iteration of the ICT artifact is evaluated by the elderly women participating in the research project. The final framework is evaluated by the women and by expert reviewers from the ICT4D and DSR domains. An internal review with members of the project team who conducted the site visits is further included.

6. Communicate: The results of this research project will be communicated through a $\mathrm{PhD}$ thesis, academic publications, project progress reports, and presentations to government departments.

\subsection{Activity theory: making the social and political dynamics visible}

Fig. 3 is a graphical representation of the components of activity theory in this research project that will be used to make the social and political dynamics in the community visible after introduction of the ICT platform.

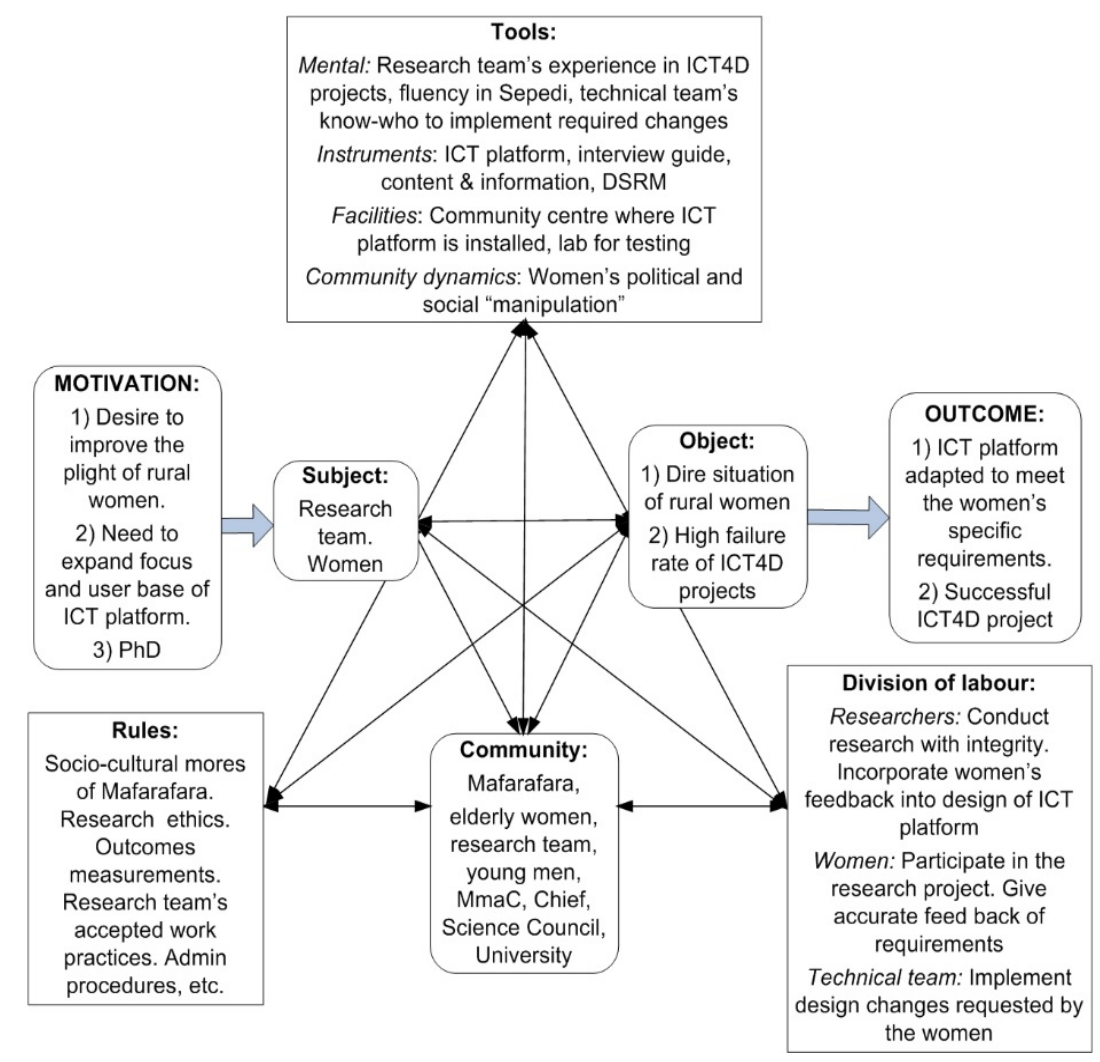

Fig. 3. Activity theory components in this research study (adapted from Engeström [31]) 


\section{Example 1: Tensions between components of the activity systems}

The purpose of the third site visit was to get feedback from the women about their experiences with the redesigned ICT platform. A number of the women stated that the CSIR should "reward" them for participating in the project. These comments highlight tensions between the tool of social dynamics that the women are utilizing to change their situation and the rules (ethics and good research practice) guiding the research process. Although the research team was not in a position to, for example, build a brick and mortar community centre for the women, they were able to ensure the women that their honest (even critical) feedback would not result in the project being cancelled and/or the ICT platform removed.

"Is there any other thing that CSIR is going to give us if we follow all the directions (sic) you gave us?"

"The CSIR should support us more because we have contributed our resources to this research. We've started our vegetable garden and have not been supported, and we have built our Centre (a mud room) and have not received any support to have a more concrete structure to secure the DD (Digital Doorway)."

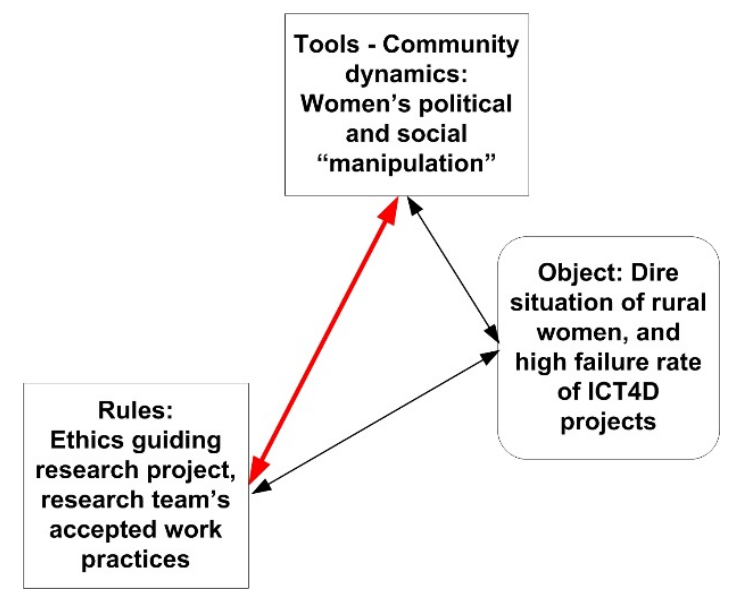

Fig. 4. Example of tensions in activity system

\section{Example 2: Hierarchical structure of human activity}

Leontiev, recognizing that an activity can happen on several layers simultaneously, formulated the hierarchical structure of human activity, depicting how a subject can interact with a number of objects at the same time [3] [27]. In this hierarchy, activities are seen as being comprised of actions, which in turn are comprised of operations. These correspond to the concepts of motive, goals and conditions. Motives, the top level goal, can be equated to human needs and represent the objective of the whole 
activity [27]. Goals are the objects at which human activities are directed. A move down the hierarchy crosses the border between conscious and automatic processes. Operations do not have their own goals but rather provide an adjustment of actions to current situations. During the third site visit, Mma C told the research team the following:

"At this moment even if we know how to open the DD...we will not touch the machine because we were not given permission to open and close that machine...even if I can go to the centre as early as eight o-clock I do not open the machine, instead I just clean and continue with sewing or marking my register of the elderly women..."

This, and similar statements, reflect the feedback regarding usage provided to the research team. After several interviews during this and subsequent site visits, it became clear that the women want a big "handing over" ceremony where CSIR management and representatives of government departments recognize them as "the owners" of the ICT platform, thereby conferring status on the women in front of the whole community. Fig. 5 shows the hierarchy of activities with expected outcomes that the women employed.

\begin{tabular}{|c|c|c|}
\hline Activity leve & Governed by & Example \\
\hline Activity & $\begin{array}{l}\text { Motive (human } \\
\text { needs - collective } \\
\text { activity) }\end{array}$ & $\begin{array}{l}\text { The women want to improve } \\
\text { their dire circumstances }\end{array}$ \\
\hline Actions & $\begin{array}{l}\text { Goals - individual } \\
\text { or group }\end{array}$ & $\begin{array}{l}\text { Through increasing their status } \\
\text { in the community }\end{array}$ \\
\hline$\stackrel{\downarrow}{\downarrow}$ & Conditions & $\begin{array}{l}\text { Women will only clean the DD } \\
\text { (which negatively impacts the } \\
\text { project) "because its not theirs" }\end{array}$ \\
\hline
\end{tabular}

Fig. 5. Hierarchy of activities by women to improve their circumstances (adapted from Karanasios [3])

\section{Conclusion}

Designing a fit-for-purpose ICT solution, which takes into account the unique socio-cultural context of a specific community is central to the success of ICT4D initiatives. DSR's requirements that an ICT artifact should have both utility and relevance, makes it an appropriate research methodology to inform the co-creation of the ICT platform with the elderly women of Mafarafara. However, as discussed DSR is not best suited to take cognizance of, and incorporate socio-political dynamics into the design process. The understanding of the unvoiced needs of the women, and their use of social and political 'manoeuvring' to meet these needs, gained through the use of 
activity theory, contribute to the success of the research project by decreasing the likelihood of failure.

This study contributes to the theoretical body of knowledge in ICT4D by demonstrating how Design Science Research (DSR) can be supplemented by the use of activity theory to lead to a more appropriate practice theory for ICT4D.

\section{References}

1. Zheng, Y.: ICT4D, Overview of Theories In. In: Manswell, R., Ang, P.H. (eds.) The International Encyclopedia of Digital Communication and Society, pp. 1-10. John Wiley \& Sons, Inc., New Jersey (2015)

2. Andersson, A., Hatakka, M.: What Are We Doing? - Theories Used in ICT4D Research. IFIP Working Group 9.4 12th International Conference on Social Implications of Computers in Developing Countries, pp. 282-300, Ocho Rios, Jamaica, May (2013)

3. Karanasios, S.: Framing ICT4D Research Using Activity Theory: A Match between the ICT4D Field and Theory? [IFIP Special Issue] Information Technologies \& International Development 10(2), 1-17 (2014)

4. Peffers, K., Tuunanen, T., Rothenberger, M.A., Chatterjee, S.: A Design Science Research Methodology for Information Systems Research. Journal of Management Information Systems 24(3), 45-77 (2007)

5. Simon, H.A.: The Sciences of the Artificial. MIT press, Cambridge, Massachusetts (1996)

6. Venable, J.R.: A Framework for Design Science Research Activities. In: Khosrow-Pour, M. (ed.) Emerging Trends and Challenges in Information Technology Management, pp. 21-24. IDEA Group Publishing, Hersey PA (2006)

7. Herselman, M., Botha, A.: Designing and Implementing an Information Technology for Rural Edcuation Development (ICT4RED) Initiative in a Resource Constrained Environment: Cofimvaba School District, Eastern Cape, South Africa. CSIR Meraka, Pretoria, South Africa (2014)

8. March, S.T., Smith, G.F.: Design and Natural Science Research on Information Technology. Decision Support Systems 15(4), 251-266 (1995)

9. Vaishnavi, V.K., Kuechler, B.: Design Science Research in Information Systems. Available from: http://desrist.org/desrist/content/design-science-research-in-informationsystems.pdf [Accessed: 30 April 2016]. (2015)

10. van Aken, J., Chandrasekaran, A., Halman, J.: Conducting and Publishing Design Science Research. Journal of Operations Managment, 1-8 (2016)

11. Drechsler, A., Hevner, A.: A Four-Cycle Model of IS Design Science Research: Capturing the Dynamic Nature of IS Artifact Design. In: Parsons, J., Tuunanen, T., Venable, J.R., Helfert, M., Donnellan, B., Kenneally, J. (eds.) 11th International Conference on Design Science Research in Information Systems and Technology (DESRIST) 2016, pp. 1-8, St. John, Canada, 23-25 May (2016)

12. Goldkuhl, G., Lind, M.: A Multi-Grounded Design Research Process. In: Winter, R., Zhao, J.L., Aier, S. (eds.) Global Perspectives on Design Science Research. 5th International Conference, DESRIST 2010, pp. 45-60. Springer, St Gallen, Switzerland, June (2010)

13. Iivari, J.: Twelve Theses on Design Science Research in Information Systems. In: Hevner, A., Chatterjee, S. (eds.) Design Research in Information Systems - Theory and Practice, vol. 22, pp. 43-62. Springer, New York (2010)

14. Dodson, L., Sterling, S.R., Bennett, J.K.: Considering Failure: Eight Years of ITID Research. In: Tongia, R., Subrahmanian, E. (eds.) Fifth International Conference on 
Information and Communication Technologies and Development (ICTD'12), pp. 56-64. ACM, Atlanta, USA (2012),Tongia, R., Subrahmanian, E.: ICT for Development - a Design Challenge? IEEE/ACM International Conference on Information and Communication Technologies and Development, ICTD 2006, Berkeley, USA, 25 - 26 May 2006 (2006)

15. Hevner, A., Chatterjee, S.: Design Research in Information Systems. Springer, New York (2010)

16. Rittel, H., Webber, M.: Planning Problems Are Wicked Problems. In: Cross, N. (ed.) Developments in Design Methodology, pp. 135-144. John Wiley \& Sons, New York, USA (1984)

17. Iivari, J.: A Paradigmatic Analysis of Information Systems as a Design Science. Scandinavian Journal of Information Systems 19(2), 39-64 (2007)

18. Dearden, A., Light, A., Kanagwa, B., Rai, I.: Technical ICT Research for Development? Getting from Research to Practice. MobileHCI 2010, September 7-10, 2010, Lisboa, Portugal (2010)

19. ANC Women's League: Women and Poverty - Discussion Document. Available from: http://www.anc.org.za/docs/discus/2014/women_povertyj.pdf [Accessed: 23 August 2016]. (2014)

20. Statistics South Africa: Social Profile of Vulnerable Groups 2002-2012. Statistics South Africa, Pretoria (2013)

21. Ozoemena, R.: Poverty Alleviation Strategies in South Africa: Creating Dignified Living for Women through Social Justice and Development. Available from: http://www.consultancyafrica.com/index.php?option=com_content\&view=article\&id=526: poverty-alleviation-strategies-in-south-africa-creating-dignified-living-for-womenthrough-social-justice-and-development\&catid=59:gender-issues-discussionpapers\&Itemid=267 [Accessed: 7 April 2012]. (2010)

22. ILO: Global Employment Trends 2012. International Labour Organisation, Geneva (2012)

23. World Bank: World Development Report 2008 - Agriculture for Development. World Bank, Washington DC (2008)

24. Buskens, I.: Agency and Reflexivity in ICT4D Research: Questioning Women's Options, Poverty, and Human Development. information technologies and international development 6 (Special Edition), 19-24 (2010)

25. Mma C. Personal discussion RE: Demographics of Mafarafara.(2014)

26. Hashim, N., Jones, M.L.: Activity Theory: A Framework for Qualitative Analysis. 4th International Qualitative Research Convention (QRC). 3-5 September, Malaysia (2007)

27. Kaptelinin, V., Nardi, B.A.: Acting with Technology: Activity Theory and Interaction Design. MIT Press, Cambridge, Massachusetts (2006)

28. Gregor, S.: The Nature of Theory in Information Systems. MIS Quarterly 30(3), 611-642 (2006)

29. Engeström, Y.: Innovative Learning in Work Teams: Analysing Cycles of Knowledge Creation in Practice. In: Engeström, Y., Miettinen, R., Punamäki, R.L. (eds.) Perspectives on Activity Theory, pp. 377-406. Cambridge University Press, Cambridge, UK (1999)

30. Ditsa, G.E.M., Davis, J.: Activity Theory as a Theoretical Foundation for Information Systems Research. In: Khosrowpour, M. (ed.) Information Resources Management Association International Conference, pp. 240-244. Idea Group Inc., Anchorage, Alaska, May (2000)

31. Engeström, Y.: Activity Theory as a Framework for Analyzing and Redesigning Work. Ergonomics 43(7), 960-974 (2000) 